\title{
The Analysis of Total Quality Management Critical Success Factors
}

DOI: 10.12776/QIP.V25I1.1514

\author{
Mirza Kulenović, Martin Folta, Ljiljan Veselinović
}

Received: 2020-10-16 Accepted: 2021-02-26 Published: 2021-03-31

\begin{abstract}
Purpose: The primary purpose of this paper is to identify the most important factors related to the successful implementation of TQM in the literature and to compare the identified factors with the existing research.

Methodology/Approach: By conducting a systematic literature review in three main stages, this research analyzes 13 empirical papers published between 1995 and 2017. Three main stages included: formulation of the problem to be solved by the systematic literature review; definition of inclusion criteria and exclusion of articles; and article search and selection.
\end{abstract}

Findings: Analysing previous research and conducting a literature review, we identify six main critical success factors (CSF): top management leadership and commitment, customer focus, training (employees), procurement management (suppliers), information and analysis, and process management.

Research Limitation/Implication: In this paper, we focused solely on the influence of TQM practices on the financial performance of a company. As such, the non-financial performance indicators were not considered.

Originality/Value of paper: This paper adds value to the existing literature as it focuses on critical factors of TQM implementation examined in relation to the financial performance of the company and provides a good basis for understanding and developing more complex models.

Category: Literature review

Keywords: TQM; quality; critical success factors; implementation; literature review; performance 


\section{INTRODUCTION}

The success of any quality management concept depends on its successful implementation within a company. In practice, however, the implementation of TQM is a complex and difficult process, and the benefits are typically not easy to achieve (Mohammad Mosadegh Rad, 2006). Therefore, exploring the key factors that determine the success of TQM implementation is an important issue.

Quality management (QM) is a concept with a long and complex history. The interpretation of the quality movement has varied across different periods, from quality control to total quality management and beyond. Thus, different definitions of QM have emerged (Bergquist et al., 2012). One of the most comprehensive definitions of TQM used in the literature considers TQM as "holistic management philosophy that strives for continuous improvement in all functions of an organisation, and it can be achieved only if the total quality concept is utilised from the acquisition of resources to customer service after the sale" (Kaynak, 2003, p.406).

Prior research suggests several possible key factors for the successful implementation of TQM. However, finding and selecting the right factors is a major challenge for businesses because there is no consensus on specific factors or a holistic framework (Ismail Salaheldin, 2009). The field of research into key factors and related measurement instruments is very broad and undefined. As such, various opinions and experiences related to factors exist in the literature (Nenadál, Vykydal and Waloszek, 2018). Therefore, research that provides an overview and structures previous research is a necessary step to establishing a common base in practice and academia.

In general, aspects of successful implementation of TQM can be drawn from four different theoretical areas: the work of quality authors (gurus), formal reward models, descriptive approaches, and empirical research (Claver, Tarí and Molina, 2003; Tarí, 2005). The research in the application of quality management comes from the contributions of quality gurus in the 1980s, when national governments have launched various models of quality awards. By the late 1990s, the vast majority of quality management literature consisted of case studies, descriptive and conceptual papers with rare exceptions of empirical studies (Hietschold, Reinhardt and Gurtner, 2014).

The main purpose of this research is to identify the most important factors related to the successful implementation of TQM in the literature and to compare the factors with the existing body of knowledge. In the first section (literature review), we explore key factors of successful implementation of TQM in the literature. However, different aspects of companies' performance have been included in these papers, which may or may not be related to financial performance. As financial performance is considered to be one of the most important measures of survival of a company, this paper provides a systematic literature review of the studies that confirmed the positive relationship between TQM practices and financial performance (subjective or objective). The reason to 
focus on the papers with the positive relationship between these constructs is to identify the factors that contribute to the improvement of the financial performance, rather than to start another discussion whether TQM contributes to the performances.

\section{LITERATURE REVIEW}

Sila and Ebrahimpour (2003) and Karuppusami and Gandhinathan (2006) conducted some of the first literature review studies and identified key factors of a successful implementation of TQM. Starting with these papers, authors' focus on empirical research and identification of new key factors have constantly increased. Today, researchers most often focus on empirical studies that incorporate the principles of national quality models (Hietschold, Reinhardt and Gurtner, 2014).

Covering the period from 1989 to 2000, Sila and Ebrahimpour (2003) analysed and compared 76 empirical studies in 23 different countries. Through their research, the authors identify five key factors for successful implementation of TQM: top management commitment and leadership, customer focus, information and analysis, training, and supplier management.

Carrying out a Pareto analysis for papers published between 1989 and 2003, Karuppusami and Gandhinathan (2006) identified 37 empirical studies by conducting reliability and validation tests in order to group key factors. The five most important factors identified by the authors are the role of management leadership and quality policy, supplier quality management, process management, customer focus, and training.

The analysis of 145 articles using a structured overview of empirical studies Hietschold, Reinhardt and Gurtner (2014) identified 11 key factors, where the five most important factors are: HRM/recognition/teamwork, top management commitment and leadership, process management, customer focus and satisfaction, and supplier partnership.

Similar research on identifying key factors for successful implementation of TQM was carried on by Aquilani et al. (2017) for the period from 1993 to 2016. In this paper, the five factors mentioned above are confirmed in their work: leadership/top management commitment/top management role, customer focus/satisfaction, training and education, measurement or metric systems/data information and analysis/quality data and reporting, supplier collaboration/management/supplier quality (management).

\section{METHODOLOGY}

For the identification, selection, and analysis of the relevant articles, we followed the stages used by Suárez et al. (2017). According to authors, a systematic 
literature review has three main stages: (1) formulation of the problem to be solved with the systematic literature review; (2) definition of inclusion criteria and exclusion of articles; and (3) article search and selection.

In the first stage, we defined the problem to be solved. The main research question was: "What are the main TQM critical success factors of the positive influence of TQM on the financial performance of a company?"

In the second stage, we defined inclusion and exclusion criteria. We covered the period from 1995 to 2017 and only scientific articles were selected which were published in journals that had a JCR (Journal Citation Reports of Thomson Reuters) or SJR (SCImago Journal and Country Rank by Scopus) impact factor. The following keywords were used: TQM, implementation, and financial performance. Papers relevant to the successful implementation were selected based on the following criteria: quantitative research; articles in English; and papers that examine the relationship between TQM and financial performance.

The third stage implied article search and selection. The first step included a total of 116 articles. After a detailed analysis of the abstracts, 94 articles were eliminated since the dependent variable had not been related to the financial performance of a company. The next phase included a complete analysis of the papers that meet the criteria. The total number of papers further analyzed is 13 (Powell, 1995; Samson and Terziovski, 1999; Douglas and Judge, 2001; Kaynak, 2003; Kaynak and Hartley, 2005; Demirbag et al., 2006a; 2006b; Sadikoglu and Olcay, 2014; Dubey and Gunasekaran, 2015; Jiménez-Jiménez et al., 2015; Valmohammadi and Roshanzamir, 2015; O'Neill, Sohal and Teng, 2016; Sweis et al., 2016). Table 1 presents the analysis of the articles identifying CSFs and used measures of financial performance. The analysis was conducted by identifying the key factors in the papers and then grouping them into broader categories.

Table 1 - Critical Success Factor Related to the Positive Influence of TQM Practices on Financial Performance

\begin{tabular}{|l|l|l|}
\hline Authors & \multicolumn{1}{|c|}{ Critical Success Factors } & \multicolumn{1}{c|}{ Performance } \\
\hline Powell (1995) & $\begin{array}{l}\text { committed leadership, adoption and } \\
\text { communication of TQM, closer } \\
\text { customer relationships, closer supplier } \\
\text { relationships, benchmarking, increased } \\
\text { training, open organization, employee } \\
\text { empowerment, zero-defects mentality, } \\
\text { flexible manufacturing, process } \\
\text { improvement, measurement }\end{array}$ & $\begin{array}{l}\text { fQM programme } \\
\text { performance }\end{array}$ \\
\hline $\begin{array}{l}\text { Samson and } \\
\text { Terziovski (1999) }\end{array}$ & $\begin{array}{l}\text { leadership, people management, } \\
\text { customer focus, strategic planning, } \\
\text { information and analysis, process } \\
\text { management }\end{array}$ & performance, business performance \\
\hline
\end{tabular}




\begin{tabular}{|c|c|c|}
\hline Authors & Critical Success Factors & Performance \\
\hline $\begin{array}{l}\text { Douglas and Judge } \\
\text { (2001) }\end{array}$ & $\begin{array}{l}\text { top management team involvement, } \\
\text { quality philosophy, emphasis on TQM- } \\
\text { oriented training, customer driven, } \\
\text { continuous improvement, management } \\
\text { by fact, total quality methods }\end{array}$ & perceived financial performance \\
\hline Kaynak (2003) & $\begin{array}{l}\text { management leadership, training, } \\
\text { employee relations, quality data and } \\
\text { reporting, supplier quality management, } \\
\text { product/service design, process } \\
\text { management }\end{array}$ & $\begin{array}{l}\text { inventory management performance, } \\
\text { quality performance, financial and } \\
\text { market performance }\end{array}$ \\
\hline $\begin{array}{l}\text { Kaynak and } \\
\text { Hartley (2005) }\end{array}$ & $\begin{array}{l}\text { management leadership, training, } \\
\text { employee relations, quality data and } \\
\text { reporting, supplier quality management, } \\
\text { product/service design, process } \\
\text { management, customer relations }\end{array}$ & $\begin{array}{l}\text { inventory management performance, } \\
\text { quality performance, financial and } \\
\text { market performance }\end{array}$ \\
\hline $\begin{array}{l}\text { Demirbag et al. } \\
\text { (2006a) }\end{array}$ & $\begin{array}{l}\text { quality data and reporting, role of top } \\
\text { management, employee relations, } \\
\text { supplier quality management, training, } \\
\text { quality policy, process management }\end{array}$ & financial performance \\
\hline $\begin{array}{l}\text { Demirbag et al. } \\
(2006 b)\end{array}$ & $\begin{array}{l}\text { quality data and reporting, role of top } \\
\text { management, employee relations, } \\
\text { supplier quality management, training, } \\
\text { quality policy, process management }\end{array}$ & financial performance \\
\hline $\begin{array}{l}\text { Sadikoglu and } \\
\text { Olcay (2014) }\end{array}$ & $\begin{array}{l}\text { overall TQM practices, leadership, } \\
\text { knowledge and process management, } \\
\text { training, supplier quality management, } \\
\text { customer focus, strategic quality } \\
\text { planning }\end{array}$ & $\begin{array}{l}\text { operational performance, inventory } \\
\text { management performance, employee } \\
\text { performance }\end{array}$ \\
\hline $\begin{array}{l}\text { Dubey and } \\
\text { Gunasekaran } \\
(2015)\end{array}$ & $\begin{array}{l}\text { human resource, quality culture, } \\
\text { motivational leadership, relationship } \\
\text { with internal and external partners }\end{array}$ & firm performance \\
\hline $\begin{array}{l}\text { Jiménez-Jiménez et } \\
\text { al. (2015) }\end{array}$ & $\begin{array}{l}\text { top management support, quality } \\
\text { information, process management, } \\
\text { product design, workforce management, } \\
\text { supplier involvement, customer } \\
\text { involvement }\end{array}$ & $\begin{array}{l}\text { customer results, people results, society } \\
\text { results, business results }\end{array}$ \\
\hline $\begin{array}{l}\text { Valmohammadi } \\
\text { and Roshanzamir } \\
(2015)\end{array}$ & $\begin{array}{l}\text { leadership, strategic planning, customer } \\
\text { focus measurement, analysis and } \\
\text { knowledge management, workforce } \\
\text { focus, operations focus }\end{array}$ & organizational performance \\
\hline $\begin{array}{l}\text { O’Neill, Sohal and } \\
\text { Teng (2016) }\end{array}$ & QM implementations & capital labour ratio, value added labour \\
\hline Sweis et al. (2016) & $\begin{array}{l}\text { customer focus, continuous } \\
\text { improvement, training and education, } \\
\text { teamwork, top management } \\
\text { commitment }\end{array}$ & $\begin{array}{l}\text { quality outcomes, customer satisfaction, } \\
\text { financial performance, innovation }\end{array}$ \\
\hline
\end{tabular}




\section{RESULTS}

Our analysis extracted 10 factors from the literature. More specifically, our results identified six factors of the successful TQM implementation, including employees, leadership, information and analysis, processes, customers, and suppliers. Although our goal was to focus on five main CSFs, we included the suppliers as the sixth one, due to the same usage frequency as the factor customers. The most common used factor was employees and leadership (in 12 out of 13 papers, 92\%), information and analysis and processes (69\%), and customers and suppliers (62\%) (Table 2).

\section{Table 2 - Main Extracted Factors}

\begin{tabular}{|c|c|}
\hline Main Extracted Factor & Critical Success Factors \\
\hline $\begin{array}{l}\text { Top management } \\
\text { leadership and } \\
\text { commitment ( } 92 \% \\
\text { coverage) }\end{array}$ & $\begin{array}{l}\text { committed leadership (Powell, 1995), leadership (Samson and Terziovski, } \\
\text { 1999; Sadikoglu and Olcay, 2014; Valmohammadi and Roshanzamir, 2015), } \\
\text { top management team involvement (Douglas and Judge, 2001), management } \\
\text { leadership (Kaynak, 2003; Kaynak and Hartley, 2005), role of top } \\
\text { management (Demirbag et al., 2006a; 2006b), motivational leadership } \\
\text { (Dubey and Gunasekaran, 2015), top management support (Jiménez-Jiménez } \\
\text { et al., 2015), top management commitment (Sweis et al., 2016) }\end{array}$ \\
\hline Employees (92\%) & $\begin{array}{l}\text { increased training, employee empowerment (Powell, 1995), people } \\
\text { management (Samson and Terziovski, 1999), emphasis on TQM-oriented } \\
\text { training (Douglas and Judge, 2001), training, employee relations (Kaynak, } \\
\text { 2003; Kaynak and Hartley, 2005; Demirbag et al., 2006a; 2006b), training } \\
\text { (Sadikoglu and Olcay, 2014), human resource (Dubey and Gunasekaran, } \\
\text { 2015), workforce management (Jiménez-Jiménez et al., 2015), workforce } \\
\text { focus (Valmohammadi and Roshanzamir, 2015), training and education, } \\
\text { teamwork (Sweis et al., 2016) }\end{array}$ \\
\hline $\begin{array}{l}\text { Information and analysis } \\
(69 \%)\end{array}$ & $\begin{array}{l}\text { information and analysis (Samson and Terziovski, 1999), management by } \\
\text { fact (Douglas and Judge, 2001), quality data and reporting (Kaynak, 2003; } \\
\text { Kaynak and Hartley, 2005; Demirbag et al., 2006a; 2006b), quality } \\
\text { information (Jiménez-Jiménez et al., 2015), analysis and knowledge } \\
\text { management (Valmohammadi and Roshanzamir, 2015), measurement } \\
\text { (Powell, 1995) }\end{array}$ \\
\hline Processes $(69 \%)$ & $\begin{array}{l}\text { process improvement (Powell, 1995), process management (Samson and } \\
\text { Terziovski, 1999; Kaynak, 2003; Kaynak and Hartley, 2005; Demirbag et al., } \\
\text { 2006a; 2006b; Jiménez-Jiménez et al., 2015), operations focus } \\
\text { (Valmohammadi and Roshanzamir, 2015), knowledge and process } \\
\text { management (Sadikoglu and Olcay, 2014) }\end{array}$ \\
\hline Customers $(62 \%)$ & $\begin{array}{l}\text { closer customer relationships (Powell, 1995), customer focus (Samson and } \\
\text { Terziovski, 1999; Sadikoglu and Olcay, 2014; Sweis et al., 2016), customer } \\
\text { driven (Douglas and Judge, 2001), customer involvement (Jiménez-Jiménez } \\
\text { et al., 2015), customer focus measurement (Valmohammadi and } \\
\text { Roshanzamir, 2015), customer relations (Kaynak and Hartley, 2005) }\end{array}$ \\
\hline Suppliers $(62 \%)$ & $\begin{array}{l}\text { closer supplier relationships (Powell, 1995), supplier quality management } \\
\text { (Kaynak, 2003; Kaynak and Hartley, 2005; Demirbag et al., 2006a; 2006b; } \\
\text { Sadikoglu and Olcay, 2014), supplier involvement (Jiménez-Jiménez et al., } \\
\text { 2015), relationship with internal and external partners (Dubey and } \\
\text { Gunasekaran, 2015) }\end{array}$ \\
\hline
\end{tabular}




\begin{tabular}{|l|l|}
\hline Main Extracted Factor & \multicolumn{1}{c|}{ Critical Success Factors } \\
\hline $\begin{array}{l}\text { Cross-cutting themes of } \\
\text { quality (53\%) }\end{array}$ & $\begin{array}{l}\text { adoption and communication of TQM (Powell, 1995), quality philosophy, } \\
\text { total quality methods (Douglas and Judge, 2001), quality policy (Demirbag et } \\
\text { al., 2006a; 2006b), overall TQM practices (Sadikoglu and Olcay, 2014), } \\
\text { quality culture (Dubey and Gunasekaran, 2015), QM implementations } \\
\text { (O’Neill, Sohal and Teng, 2016) }\end{array}$ \\
\hline $\begin{array}{l}\text { Strategic planning } \\
(23 \%)\end{array}$ & $\begin{array}{l}\text { strategic planning (Samson and Terziovski, 1999; Valmohammadi and } \\
\text { Roshanzamir, 2015), strategic quality planning (Sadikoglu and Olcay, 2014) }\end{array}$ \\
\hline $\begin{array}{l}\text { Product/service design } \\
(23 \%)\end{array}$ & $\begin{array}{l}\text { product/service design (Kaynak, 2003; Kaynak and Hartley, 2005), product } \\
\text { design (Jiménez-Jiménez et al., 2015) }\end{array}$ \\
\hline $\begin{array}{l}\text { Continuous } \\
\text { improvement (15\%) }\end{array}$ & continuous improvement (Douglas and Judge, 2001; Sweis et al., 2016) \\
\hline
\end{tabular}

As shown in Table 3, the factors of successful implementation of TQM that we identified closely correspond to the existing factors highlighted in the existing literature. Top management leadership and commitment, customer focus, training (employees), and suppliers are found in all five studies, procurement management (suppliers), and process management in four studies, while information and analysis in three studies.

Table 3 - Key Factors for Successful Implementation According to Different Authors

\begin{tabular}{|c|c|c|c|c|}
\hline \multicolumn{5}{|c|}{ Comparison to the Previous Literature Review } \\
\hline Our research & $\begin{array}{l}\text { Sila and } \\
\text { Ebrahimpour } \\
(2003)\end{array}$ & $\begin{array}{l}\text { Karuppusami and } \\
\text { Gandhinathan } \\
(2006)\end{array}$ & $\begin{array}{l}\text { Hietschold, } \\
\text { Reinhardt and } \\
\text { Gurtner (2014) }\end{array}$ & $\begin{array}{l}\text { Aquilani et al. } \\
\text { (2017) }\end{array}$ \\
\hline $\begin{array}{l}\text { top management } \\
\text { leadership and } \\
\text { commitment }\end{array}$ & $\begin{array}{l}\text { top management } \\
\text { commitment and } \\
\text { leadership }\end{array}$ & $\begin{array}{l}\text { the role of } \\
\text { management } \\
\text { leadership and } \\
\text { quality policy }\end{array}$ & $\begin{array}{l}\text { top management } \\
\text { commitment and } \\
\text { leadership }\end{array}$ & $\begin{array}{l}\text { leadership/top } \\
\text { management } \\
\text { commitment/top } \\
\text { management role }\end{array}$ \\
\hline customers & customer focus & customer focus & $\begin{array}{l}\text { customer focus and } \\
\text { satisfaction }\end{array}$ & $\begin{array}{l}\text { customer } \\
\text { focus/satisfaction }\end{array}$ \\
\hline employees & training & training & $\begin{array}{l}\text { HRM/recognition/t } \\
\text { eamwork }\end{array}$ & $\begin{array}{l}\text { training and } \\
\text { education }\end{array}$ \\
\hline suppliers & $\begin{array}{l}\text { supplier } \\
\text { management }\end{array}$ & $\begin{array}{l}\text { supplier quality } \\
\text { management }\end{array}$ & $\begin{array}{l}\text { supplier } \\
\text { partnership }\end{array}$ & $\begin{array}{l}\text { supplier } \\
\text { collaboration/ } \\
\text { management/suppli } \\
\text { er quality } \\
\text { (management) }\end{array}$ \\
\hline $\begin{array}{l}\text { information and } \\
\text { analysis }\end{array}$ & $\begin{array}{l}\text { information and } \\
\text { analysis }\end{array}$ & - & - & $\begin{array}{l}\text { measurement or } \\
\text { metric } \\
\text { systems/data } \\
\text { information and } \\
\text { analysis/ } \\
\text { quality data and } \\
\text { reporting }\end{array}$ \\
\hline processes & - & $\begin{array}{l}\text { process } \\
\text { management }\end{array}$ & $\begin{array}{l}\text { process } \\
\text { management }\end{array}$ & $\begin{array}{l}\text { Process quality } \\
\text { management }\end{array}$ \\
\hline
\end{tabular}




\subsection{Top Management Leadership and Commitment}

According to the existing literature, the leadership and commitment of top management are undoubtedly one of the most important factors underlying the success of TQM. TQM is a management philosophy, and therefore the initiation of quality activities comes from the level of top management. Top management leadership and commitment relate to factors that measure the involvement and support of the quality of individuals at higher levels of an organization's hierarchy (Hietschold, Reinhardt and Gurtner, 2014). Thus, Oakland (2011, p.517) stated: "TQM must start at the top, where serious obsession and commitment to quality and leadership need to be demonstrated. Middle management also has a key role to play in communicating the message". The factor of top management's leadership and commitment imply that managers should be focused on aligning quality goals with their vision, on implementing quality as a part of corporate culture, and creating a culture in which continuous improvement is supported, and reluctance to change is minimized. Establishing a culture of quality that is supported by overall business strategy is crucial to the success of an organization. Therefore, it is important that leaders have competencies related to planning, communication, management, vision development and implementation as well as ensuring employee participation (Paulová and Míkva, 2011).

\subsection{Focus on the Customer and Customer Satisfaction}

Some authors consider focusing on customer satisfaction to be a key factor in success, while others acknowledge customer satisfaction as a result of the successful implementation of TQM (Porter and Parker, 1993; Yusof and Aspinwall, 2000). Furthermore, Issac, Rajendran, and Anantharaman (2004) confirmed that customer satisfaction is part of the philosophy of TQM. This factor focuses on identification and meeting current and emerging customer needs (Nair, 2006). Considered in a long-term perspective, organizations can not "survive" without their customers. Consequently, issues related to customer retention or customer loyalty are considered crucial today (Vykydal, Halfarová and Nenadál, 2013). Organizations need to establish an open relationship with customers to receive information about their preferences and to receive feedback on how to fulfil these requirements in the best possible way (Das, Paul and Swierczek, 2008; Flynn, Schroeder and Sakakibara, 1994). Consumer opinions can improve the quality of products and services and should, therefore, be included at every stage of the product development process (Singh and Smith, 2004). Since customer satisfaction affects the success or failure of a company, an organization should be able to respond quickly to changing consumer needs (Mehra, Hoffman and Sirias, 2001). It is, therefore, important that every employee of a company is involved and committed to establishing and maintaining a high level of customer satisfaction. 


\subsection{Employees: Training and Education}

Employee related factors are most often manifested through employee training and education; that is, the focus is on employee participation. By actively participating, employees acquire new knowledge, learn how to identify problems more efficiently, and to solve problems more effectively. The resulting understanding of the importance of quality leads to an increased commitment to TQM. This change in attitude makes employees to feel as a part of the organization and enables the creation of a quality culture for the entire company. Training and education are considered to be the most important aspects of human resource management, i.e., it is considered to be "a key to a successful implementation of TQM along the dimensions of cost reduction and profit increase" (Kassicieh and Yourstone, 1998, p.36). Training needs, employee motivation, and improvement of future effective evaluation are essential for building a quality performance evaluation based on quality (Aquilani et al., 2017).

\subsection{Suppliers: Supplier Management and Cooperation with Suppliers}

Creating and maintaining a superior supplier relationship is another critical factor. One of the prerequisites for the success of production process management is a choice of reliable suppliers. As such, this issue deserves special attention (Pech and Vaněček, 2020). Supply quality is an important aspect of TQM, as parts provided by suppliers are often the main source of quality problems (Zhang, Waszink and Wijngaard, 2000). Poor quality leads to additional costs and can damage the image of the product or the entire company. As a result of this interconnectedness, record keeping and providing quality feedback are often considered extremely important in identifying problems and improving the supplier process (Saraph, Benson and Schroeder, 1989). Longterm relationships between the organization and selected suppliers reduce the cost of quality control and costs of poor product quality and ensure a continuous supply of the required quality components (Das, Paul and Swierczek, 2008; Zhang, Waszink and Wijngaard, 2000). Improvements in the quality of products or services require that all major suppliers comply with the organization's quality specifications (González-Benito, Martínez-Lorente and Dale, 2003).

\subsection{Information and Analysis}

The information system is a key part of the quality management infrastructure. To maintain and continually improve quality, organizations need a flow of reliable information (Rao, Solis and Raghunathan, 1999). Collecting relevant data is essential to monitor the current quality status. Organizations can not properly evaluate the quality of products and services unless they can measure status before and after improvement activities (Jayaram, Ahire and Dreyfus, 2010). Quality data and reporting include a high level of documentation, monitoring, and feedback. Documenting the processes, identifying the level of 
waste and damage in the production process, as well as keeping information easily accessible to employees, are considered important factors underlying an organization's success (Kaynak, 2003). Measurement assists in evaluating the quality of processes and products or services, which is one of the most important methods for checking continuous improvement, monitoring processes, analyzing, and correcting deficiencies from required standards. For a process to be managed, primary data must be collected (Malik, Sinha and Blumenfeld, 2012).

\subsection{Process Management}

The process is a series of interdependent activities that consume resources and convert inputs into outputs. Organizations need to manage processes to function without operational errors (Zhang, Waszink and Wijngaard, 2000). The importance of process management is based on the assumption that organizations are systems of interconnected processes and that process improvement determines performance improvement (Deming, 1986; Samson and Terziovski, 1999). The importance of this in implementing TQM stems from its ability to add value to processes, increase quality levels, and raise enterprise productivity (Bigwood, 1997; Motwani, 2001). To achieve better product and service quality, organizations need to identify key processes and improve them on a continuous basis (Zhang, Waszink and Wijngaard, 2000). The application of appropriate statistical methods to ensure a high level of process control and the use of assessment results to acquire process knowledge have also been emphasized as important factors in several empirical studies (Saraph, Benson and Schroeder, 1989; Flynn, Schroeder and Sakakibara, 1994; Claver, Tari and Molina, 2003). Furthermore, process redesign and reengineering can lead to dramatic performance improvements (Samson and Terziovski, 1999).

\section{CONCLUSION}

The main purpose of this paper has been to identify the most commonly used critical success factors in the TQM implementation. Analysing previous research and conducting a literature review, we have identified six main critical success factors: top management leadership and commitment, customer focus, training (employees), procurement management (suppliers), information and analysis, and process management. This paper adds value to the existing literature as it focuses on critical factors of TQM implementation examined in relation to the financial performance of a company and as it provides a good basis for creating more complex models to explore the impact of TQM practices on company performance. The future research might focus on other dependent variables, such as employee satisfaction and customer satisfaction. By comparing the results with previous research, similarities, and shortcomings in identifying factors for successful implementation of TQM can be identified. The interplay between these factors and the financial performance might depend on the external factors, and future studies should elaborate the mechanism by which these factors 
contribute to the financial performance of a company in specific industries. Case studies would be especially useful for managers in order to demonstrate the importance of TQM factors and to explain the mechanism of how previously identified critical success factors of TQM influence financial performance.

\section{REFERENCES}

Aquilani, B., Silvestri, C., Ruggieri, A. and Gatti, C., 2017. A systematic literature review on total quality management critical success factors and the identification of new avenues of research. The TQM Journal, [e-journal] 29(1), pp.184-213. DOI: 10.1108/TQM-01-2016-0003.

Bergquist, B., Garvare, R., Eriksson, H., Hallencreutz, J., Langstrand, J., Vanhatalo, E. and Zobel, T., 2012. Alive and kicking-but will Quality Management be around tomorrow? A Swedish academia perspective. Quality Innovation Prosperity, [e-journal] 16(2), pp.1-18. DOI: 10.12776/qip.v16i2.53.

Bigwood, M., 1997. Total quality management at work: Development of an effective competitive analysis process. Industrial Marketing Management, [e-journal] 26(5), pp.459-466. DOI: 10.1016/S0019-8501(96)00157-5.

Claver, E., Tarí, J. and Molina, J., 2003. Critical factors and results of quality management: An empirical study. Total Quality Management \& Business Excellence, [e-journal] 14(1), pp.91-118. DOI: 10.1080/14783360309709.

Das, A., Paul, H. and Swierczek, F., 2008. Developing and validating total quality management (TQM) constructs in the context of Thailand's manufacturing industry. Benchmarking: An International Journal, [e-journal] 15(1), pp.52-72. DOI: 10.1108/14635770810854344.

Deming, W.E., 1986. Out of the crisis. Massachusetts Institute of Technology. Cambridge, MA: Center for advanced engineering study.

Demirbag, M., Lenny Koh, S., Tatoglu, E. and Zaim, S., 2006a. TQM and market orientation's impact on SMEs' performance. Industrial Management \& Data Systems, [e-journal] 106(8), pp.1206-1228. DOI: 10.1108/02635570610710836.

Demirbag, M., Tatoglu, E., Tekinkus, M. and Zaim, S., 2006b. An analysis of the relationship between TQM implementation and organizational performance. Journal of Manufacturing Technology Management, [e-journal] 17(6), pp.829-847. DOI: 10.1108/17410380610678828.

Douglas, T. and Judge, W., 2001. Total Quality Management Implementation and Competitive Advantage: The Role of Structural Control and Exploration. Academy of Management Journal, [e-journal] 44(1), pp.158-169. DOI: $10.5465 / 3069343$. 
Dubey, R. and Gunasekaran, A., 2014. Exploring soft TQM dimensions and their impact on firm performance: some exploratory empirical results. International Journal of Production Research, [e-journal] 53(2), pp.371-382. DOI: 10.1080/00207543.2014.933909.

Flynn, B., Schroeder, R. and Sakakibara, S., 1994. A framework for quality management research and an associated measurement instrument. Journal of operations management, [e-journal] 11(4), pp.339-366. DOI: 10.1016/S02726963(97)90004-8.

González-Benito, J., Martínez-Lorente, A. and Dale, B., 2003. A study of the purchasing management system with respect to total quality management. Industrial Marketing Management, [e-journal] 32(6), pp.443-454. DOI: 10.1016/S0019-8501(02)00231-6.

Hietschold, N., Reinhardt, R. and Gurtner, S., 2014. Measuring critical success factors of TQM implementation successfully - a systematic literature review. International Journal of Production Research, [e-journal] 52(21), pp.6254-6272. DOI: 10.1080/00207543.2014.918288.

Ismail Salaheldin, S., 2009. Critical success factors for TQM implementation and their impact on performance of SMEs. International Journal of Productivity and Performance Management, [e-journal] 58(3), pp.215-237. DOI: 10.1108/17410400910938832.

Issac, G., Rajendran, C. and Anantharaman, R., 2004. A Conceptual Framework for Total Quality Management in Software Organizations. Total Quality Management \& Business Excellence, [e-journal] 15(3), pp.307-344. DOI: 10.1080/1478336042000183398.

Jayaram, J., Ahire, S. and Dreyfus, P., 2009. Contingency relationships of firm size, TQM duration, unionization, and industry context on TQM implementationA focus on total effects. Journal of operations management, [e-journal] 28(4), pp.345-356. DOI: 10.1016/j.jom.2009.11.009.

Jiménez-Jiménez, D., Martinez-Costa, M., Martínez-Lorente, A.R. and Rabeh, H.A.D., 2015. Total quality management performance in multinational companies: A learning perspective. The TQM Journal, [e-journal] 27(3), pp.328-340. DOI: 10.1108/TQM-01-2014-0002.

Karuppusami, G. and Gandhinathan, R., 2006. Pareto analysis of critical success factors of total quality management: A literature review and analysis. The TQM magazine, [e-journal] 18(4), pp.372-385. DOI: 10.1108/09544780610671048.

Kassicieh, S.K. and Yourstone, S.A., 1998. Training, performance evaluation, rewards, and TQM implementation success. Journal of Quality Management, [e-journal] 3(1), pp.25-38. DOI: 10.1016/S1084-8568(99)80102-3. 
Kaynak, H., 2003. The relationship between total quality management practices and their effects on firm performance. Journal of operations management, [e-journal] 21(4), pp.405-435. DOI: 10.1016/S0272-6963(03)00004-4.

Kaynak, H. and Hartley, J.L., 2005. Exploring quality management practices and high tech firm performance. The Journal of High Technology Management Research, [e-journal] 16(2), pp.255-272. DOI: 10.1016/j.hitech.2005.10.002.

Malik, A., Sinha, A. and Blumenfeld, S., 2012. Role of quality management capabilities in developing market-based organisational learning capabilities: Case study evidence from four Indian business process outsourcing firms. Industrial Marketing Management, [e-journal] 41(4), pp.639-648. DOI: 10.1016/j.indmarman.2011.06.037.

Mehra, S., Hoffman, J.M. and Sirias, D., 2001. TQM as a management strategy for the next millennia. International Journal of Operations \& Production Management, [e-journal] 21(5/6), pp.855-876. DOI: 10.1108/01443570110390534.

Mohammad Mosadegh Rad, A., 2006. The impact of organizational culture on the successful implementation of total quality management. The TQM magazine, [e-journal] 18(6), pp.606-625. DOI: 10.1108/09544780610707101.

Motwani, J., 2001. Measuring critical factors of TQM. Measuring business excellence, [e-journal] 5(2), pp.27-30. DOI: 10.1108/13683040110397284.

Nair, A., 2006. Meta-analysis of the relationship between quality management practices and firm performance-implications for quality management theory development. Journal of operations management, [e-journal] 24(6), pp.948-975. DOI: 10.1016/j.jom.2005.11.005.

Nenadál, J., Vykydal, D. and Waloszek, D., 2018. Organizational excellence: approaches, models and their use at Czech organizations. Quality Innovation Prosperity, [e-journal] 22(2), pp. 47-64. DOI: 10.12776/QIP.V22I2.1129.

O'Neill, P., Sohal, A. and Teng, C.W., 2016. Quality management approaches and their impact on firms' financial performance-An Australian study. International Journal of Production Economics, [e-journal] 171, pp.381-393. DOI: 10.1016/j.jpe.2015.07.015.

Oakland, J.S., 2011. Leadership and policy deployment: the backbone of TQM. Total Quality Management \& Business Excellence, [e-journal] 22(5), pp.517-534. DOI: 10.1080/14783363.2011.579407.

Paulová, I. and Míkva, M., 2011. Leadership-The key element in improving quality management. Quality innovation prosperity, 15(1), pp. 27-36.

Pech, M. and Vaněček, D., 2020. Supplier Performance Management in Context of Size and Sector Characteristics of Enterprises. Quality Innovation Prosperity, [e-journal] 24(1), pp. 88-103. DOI: 10.12776/QIP.V24I1.1407. 
Porter, L.J. and Parker, A.J., 1993. Total quality management-the critical success factors. Total quality management, [e-journal] 4(1), pp.13-22. DOI: 10.1080/09544129300000003.

Powell, T.C., 1995. Total quality management as competitive advantage: a review and empirical study. Strategic management journal, [e-journal] 16(1), pp.15-37. DOI: 10.1002/smj.4250160105.

Rao, S.S., Solis, L.E. and Raghunathan, T.S., 1999. A framework for international quality management research: development and validation of a measurement instrument. Total Quality Management, [e-journal] 10(7), pp.1047-1075. DOI: 10.1080/0954412997226.

Sadikoglu, E. and Olcay, H., 2014. The effects of total quality management practices on performance and the reasons of and the barriers to TQM practices in Turkey. Advances in Decision Sciences, [e-journal] 2014(2), pp.1-17. DOI: $10.1155 / 2014 / 537605$.

Samson, D. and Terziovski, M., 1999. The relationship between total quality management practices and operational performance. Journal of operations management, [e-journal] 17(4), pp.393-409. DOI: 10.1016/S02726963(98)00046-1.

Saraph, J.V., Benson, P.G. and Schroeder, R.G., 1989. An instrument for measuring the critical factors of quality management. Decision sciences, [e-journal] 20(4), pp.810-829. DOI: 10.1111/j.1540-5915.1989.tb01421.x.

Sila, I. and Ebrahimpour, M., 2003. Examination and comparison of the critical factors of total quality management (TQM) across countries. International journal of production research, [e-journal] 41(2), pp.235-268. DOI: 10.1080/0020754021000022212.

Singh, P.J. and Smith, A.J., 2004. Relationship between TQM and innovation: an empirical study. Journal of Manufacturing Technology Management, [e-journal] 15(5), pp.394-401. DOI: 10.1108/17410380410540381.

Suárez, E., Calvo-Mora, A., Roldán, J.L. and Periáñez-Cristóbal, R., 2017. Quantitative research on the EFQM excellence model: A systematic literature review (1991-2015). European Research on Management and Business Economics, [e-journal] 23(3), pp.147-156. DOI: 10.1016/j.iedeen.2017.05.002.

Sweis, R.J., Saleh, R.A., Al-Etayyem, R.H., Qasrawi, B.T. and Mahmoud, A.M.A., 2016. Total quality management practices and organisational performance in Jordanian courier services. International Journal of Productivity and Quality Management, [e-journal] 19(2), pp.258-276. DOI: 10.1504/IJPQM.2016.078889.

Tarí, J.J., 2005. Components of successful total quality management. The TQM magazine, [e-journal] 17(2), pp.182-194. DOI: 10.1108/09544780510583245. 
Valmohammadi, C. and Roshanzamir, S., 2015. The guidelines of improvement: Relations among organizational culture, TQM and performance. International Journal of Production Economics, [e-journal] 164, pp.167-178. DOI: 10.1016/j.ijpe.2014.12.028.

Vykydal, D., Halfarová, P. and Nenadál, J., 2013. Customer Loyalty Measurement at Czech Organizations. Quality Innovation Prosperity, [e-journal] 17(1), pp. 28-38. DOI: 10.12776/QIP.V17I1.66.

Yusof, S.R.M. and Aspinwall, E., 2000. TQM implementation issues: review and case study. International Journal of Operations \& Production Management, [e-journal] 20(6), pp.634-655. DOI: 10.1108/01443570010321595.

Zhang, Z., Waszink, A.B. and Wijngaard, J., 2000. An instrument for measuring TQM implementation for Chinese manufacturing companies. International Journal of Quality \& Reliability Management, [e-journal] 17(7), pp.730-755. DOI: 10.1108/02656710010315247.

\section{ABOUT AUTHORS}

Mirza Kulenović0000-0002-9372-300x (M.K.) - College Prof., Department of Business Economics, University College "CEPS - Centre for Business Studies" Kiseljak, Bosnia and Herzegovina, e-mail: mirza.kulenovic@ceps.edu.ba.

Martin Folta ${ }^{0000-0002-4508-5760}$ (M.F.) - Assist. Prof., Department of Production, Logistics and Quality Management, ŠKODA AUTO University, Mladá Boleslav, Czech Republic, e-mail: martin.folta@ savs.cz.

Ljiljan Veselinovićc000-0003-2585-5016(LJ.V.) - Assist. Prof., School of Economics and Business, University of Sarajevo, e-mail: 1jiljan.veselinovic@efsa.unsa.ba.

\section{AUTHOR CONTRIBUTIONS}

Validation, LJ.V.; Writing, M.K.; Original draft preparation, M.K.; Review and editing, M.F. and LJ.V.; Visualization, M.F.

\section{CONFLICTS OF INTEREST}

The authors declare no conflict of interest. The funders had no role in the design of the study; in the collection, analyses, or interpretation of data; in the writing of the manuscript, or in the decision to publish the results.

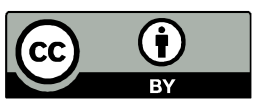

(C) 2021 by the authors. Submitted for possible open access publication under the terms and conditions of the Creative Commons Attribution (CC-BY) license (http://creativecommons.org/licenses/by/4.0/). 